\title{
If The Banks Are Doing So Well, Why Can't I Get A Loan? Regulatory Constraints to Financial Inclusion in Indonesia
}

\section{Citation}

Rosengard, Jay K., and A. Prasetyantoko. 2011. If The Banks Are Doing So Well, Why Can't I Get A Loan? Regulatory Constraints to Financial Inclusion in Indonesia. Asian Economic Policy Review, 6(2): 273-296.

\section{Published Version}

http://dx.doi.org/10.1111/j.1748-3131.2011.01205.x

\section{Permanent link}

http://nrs.harvard.edu/urn-3:HUL.InstRepos:8705903

\section{Terms of Use}

This article was downloaded from Harvard University's DASH repository, and is made available under the terms and conditions applicable to Other Posted Material, as set forth at http:// nrs.harvard.edu/urn-3:HUL.InstRepos:dash.current.terms-of-use\#LAA

\section{Share Your Story}

The Harvard community has made this article openly available.

Please share how this access benefits you. Submit a story.

\section{Accessibility}




\title{
If the Banks are Doing So Well, Why Can't I Get a Loan? Regulatory Constraints to Financial Inclusion in Indonesia
}

\author{
Jay K. ROSENGARD ${ }^{1} \dagger$ and A. PRASETYANTOKO² \\ ${ }^{1}$ Harvard University and ${ }^{2}$ Atma Jaya Catholic University
}

Indonesia's financial sector has two paradoxes: (i) Indonesia has been a global leader in microfinance for the past 25 years, but access to microfinance services is declining; and (ii) Indonesia's commercial banks are liquid, solvent, and profitable, and the Indonesian economy has been doing well over the past decade, but small and medium enterprises are facing a credit crunch. Although Indonesia is underbanked, most commercial banks have been unresponsive to unmet effective demand. The behavior of banks has been in their own short-term best interests, primarily because of the unintended consequences of Indonesia's financial sector reregulation after the East Asian crisis and contradictory monetary policies, which have produced a prudentially sound but inefficient, narrow, and homogenized banking oligopoly. Indonesia should not respond to financial exclusion by artificially pumping out and administratively allocating more credit. Instead, it should promulgate smart regulation so that banks maintain their sound risk management without pursuing noncompetitive and noninclusive business practices.

Key words: bank regulation, financial sector reform, Indonesia, microfinance, SME finance

JEL codes: G21, O16

\section{The Twin Paradoxes of Indonesia's Financial Sector}

The financial sector in Indonesia is currently characterized by two perplexing paradoxes:

1 Although Indonesia has been a global leader in microfinance outreach and innovation for the past 25 years, access to microfinance services is now declining.

2 Although Indonesia's commercial banks are liquid, solvent, and profitable, and the Indonesian economy has been doing quite well over the past decade, small and medium enterprises (SMEs) are now facing a credit crunch.

In Section 2, we demonstrate that contrary to popular perceptions, Indonesia is underbanked, especially for microfinance and SME finance. This is true whether assessed nationally by examining macro figures of financial depth, or determined at the household

An earlier version of this paper was presented at the Twelfth Asian Economic Policy Review Conference on the theme of "Developments in Asian Finance" on May 20, 2011 in Osaka. The authors are grateful to the participants for their useful comments, particularly the editors and our two discussants, Hal Hill and Seiro Ito.

†Correspondence: Jay K. Rosengard, Harvard Kennedy School, 79 John F. Kennedy Street, Cambridge, MA 02138, USA. Email: jay_rosengard@harvard.edu 
and firm level by documenting unmet effective demand of micro, small, and medium enterprises (MSMEs, or UMKMs, Usaha Mikro, Kecil, dan Menengah in Indonesian).

In Section 3, we look at financial exclusion from the supply side. We demonstrate that despite potentially lucrative unserved or underserved markets, both microfinance institutions (MFIs) and mainstream commercial banks, in choosing to invest their resources elsewhere, are acting rationally in response to perverse incentives created by the current monetary policy and regulatory regime of Bank Indonesia (BI, the central bank).

In Section 4, we examine this disabling rather than enabling regulatory context in depth. We focus in particular on the way the government has unintentionally created barriers to outreach and innovation for MFIs, as well as generated incentives for commercial banks to forsake SME finance in favor of consumer finance and alternative nonloan investments in an environment with significant barriers to competition.

In Section 5, we conclude with a discussion of the challenges of deregulation, reregulation, and smart regulation, and offer recommendations for mitigating counterproductive monetary policies and past regulatory failures without creating other perverse incentives for MSME institutions.

\section{Unmet Effective Demand for Financial Services}

Indonesia is clearly underbanked by standard measures of financial depth. This is of great concern to the government in light of the voluminous literature on the relationship between financial sector development and economic growth. While policymakers do not want a repeat of the credit-fueled asset bubbles that preceded the 1997-1998 East Asian financial crisis and the subsequent collapse of Indonesia's banking system, they are concerned that lack of access to financial services is hampering both the rate and equity of Indonesia's economic growth.

Using the latest version of the Financial Structure Dataset presented in Beck et al. (2010) and updated in November 2010, not only is the size of Indonesia's financial sector considerably smaller than comparable countries, but it has shrunk significantly from pre-East Asian crisis levels as a share of the nation's economy. Table 1 shows that liquid liabilities, bank deposits, and both private credit and assets of deposit money banks have all declined as a percentage of gross domestic product (GDP) since 1999, and in 2009 were generally lower than India, Pakistan, the Philippines, and Thailand (lower middle-income countries); Malaysia (an Association of Southeast Asian Nations [ASEAN] upper middleincome country); and the USA (a high-income country). ${ }^{1}$

The International Monetary Fund's Financial Access Survey (IMF, 2010) contains similar figures for Indonesia: in 2009, outstanding loans from commercial banks were $24 \%$ of GDP, and outstanding deposits with commercial banks were $33 \%$ of GDP. ${ }^{2}$ The above-cited figures focus on banks because four-fifths of Indonesia's formal financial system assets are held by banks.

However, physical access to formal financial institutions does not appear to be a significant constraint. In the World Bank's nationwide survey on financial access in 


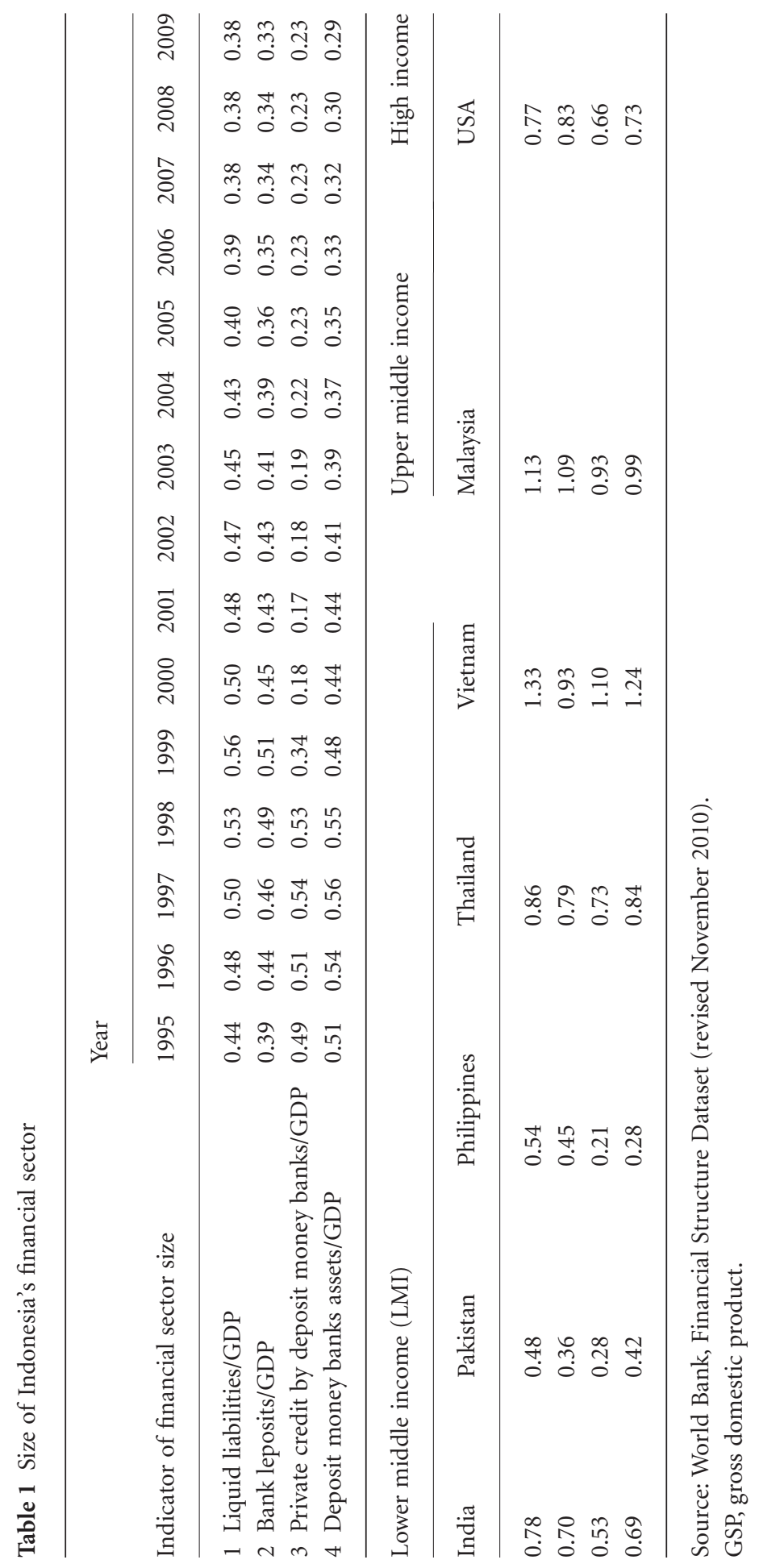


Indonesia, ${ }^{3} 95 \%$ of the respondents characterized physical accessibility of banking facilities as "convenient" or "very convenient." "This is consistent with the steady rise in number of financial institution offices and other outlets shown in Table 2 despite the steady decline in total private banks (see section 4 for a discussion of the government's policy to consolidate the banking sector).

Indonesia is still underbanked even when nonbank financial institutions are included, based on the results of the World Bank (2010) household survey. Although savings were the financial service in greatest demand, and 50\% of households save at formal financial institutions, only an additional 18\% saved at informal institutions, leaving one-third of households that said they did not save at all. On the credit side, while just $17 \%$ of households had loans from banks and another $43 \%$ borrowed from a variety of nonbank sources, there were still $40 \%$ who did not borrow at all. Access should not be confused with utilization, nor should all exclusion be deemed involuntary, but of the $40 \%$ who had no loans, only one-fifth said it was because they intentionally chose not to borrow. In contrast, $79 \%$ of households that did not save said it was because they had no money, but this implies that they might still save in traditional noncash forms, such as livestock and jewelry, in keeping with the belief that poor families cannot afford not to save. ${ }^{5}$

There are additional indications of unmet effective demand for financial services today in Indonesia, particularly regarding loans for MSMEs. ${ }^{6}$

At the macro level, since 2004 GDP has steadily grown between $5 \%$ and $7 \%$, inflation has been contained to single digits for most of this period, and the exchange rate has remained stable at between Rp8,500 and Rp9,500 to the US dollar most of the time. ${ }^{7}$ Unlike the period in Indonesia following the East Asian crisis described in Agung et al. (2001) or the current situation in the USA in the aftermath of the global economic crisis, there should be many creditworthy MSMEs amid a relatively strong economy - the traditional banker's rationale for a credit crunch, fear of nonperforming loans (NPLs) in a weak economy, rings hollow in this context.

At the micro level, several field surveys over the past decade besides World Bank (2010) indicate that lack of access to credit for viable MSMEs wishing to borrow is a significant constraint to their development. These include Bank Rakyat Indonesia's (BRI's) 2001 nationwide stratified purposive sample survey of 1469 households in 10 provinces (Rosengard et al., 2001) and its 2002 follow-up survey of 1438 households in six provinces (Johnston \& Morduch, 2008); BI's 2005 survey of 11,000 MSMEs in 11 provinces (Bank Indonesia, 2005b); and the World Bank's 2006 Rural Investment Climate Survey of 2549 nonfarm enterprises and 2782 households in six rural kabupaten (districts) located throughout the country (World Bank, 2006; 2007).

This unmet effective demand had been well documented and has been acknowledged by the government, giving rise to BI's vigorously promoted Financial Inclusion Program (Program Perluasan Akses Kepada Lembaga Keuangan). Nonetheless, the response of banks to expand MSME lending has been underwhelming. The next section explores the capacity and willingness of banks to broaden their coverage of the MSME sector. 


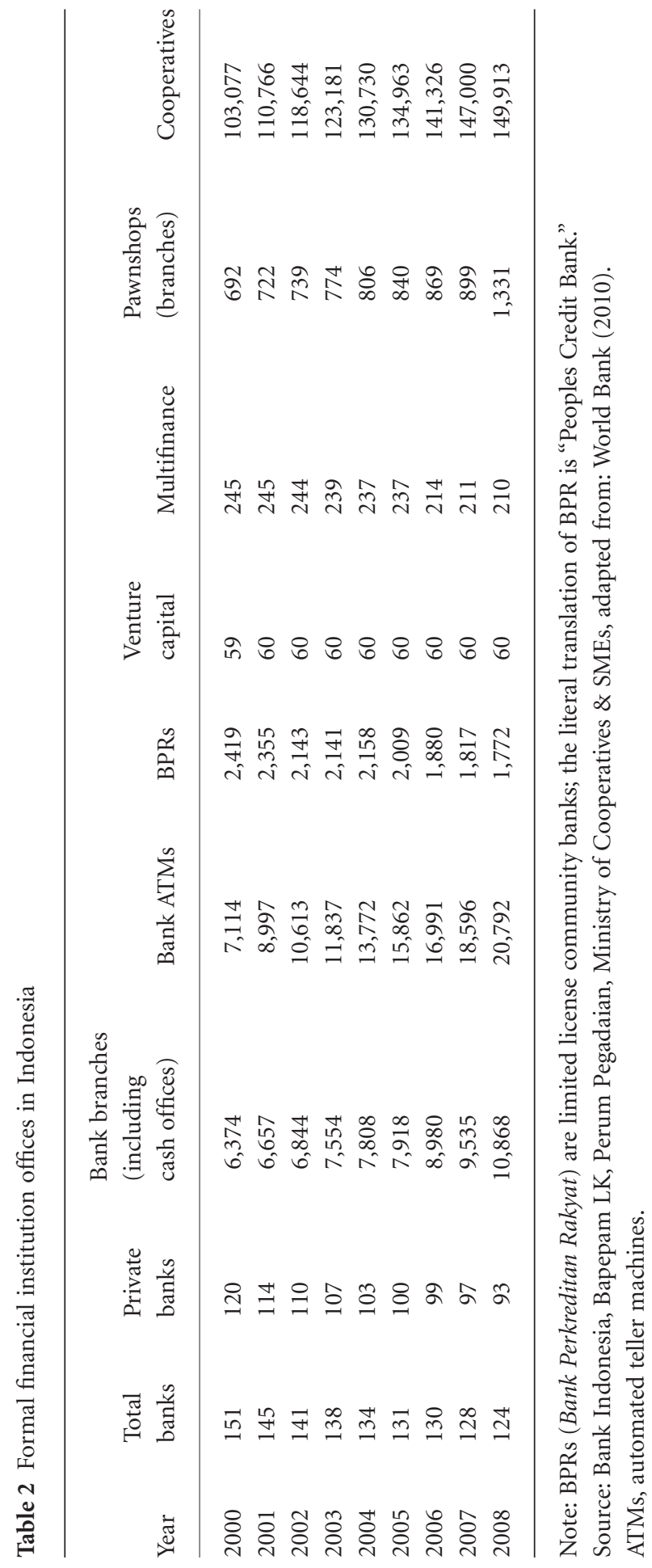




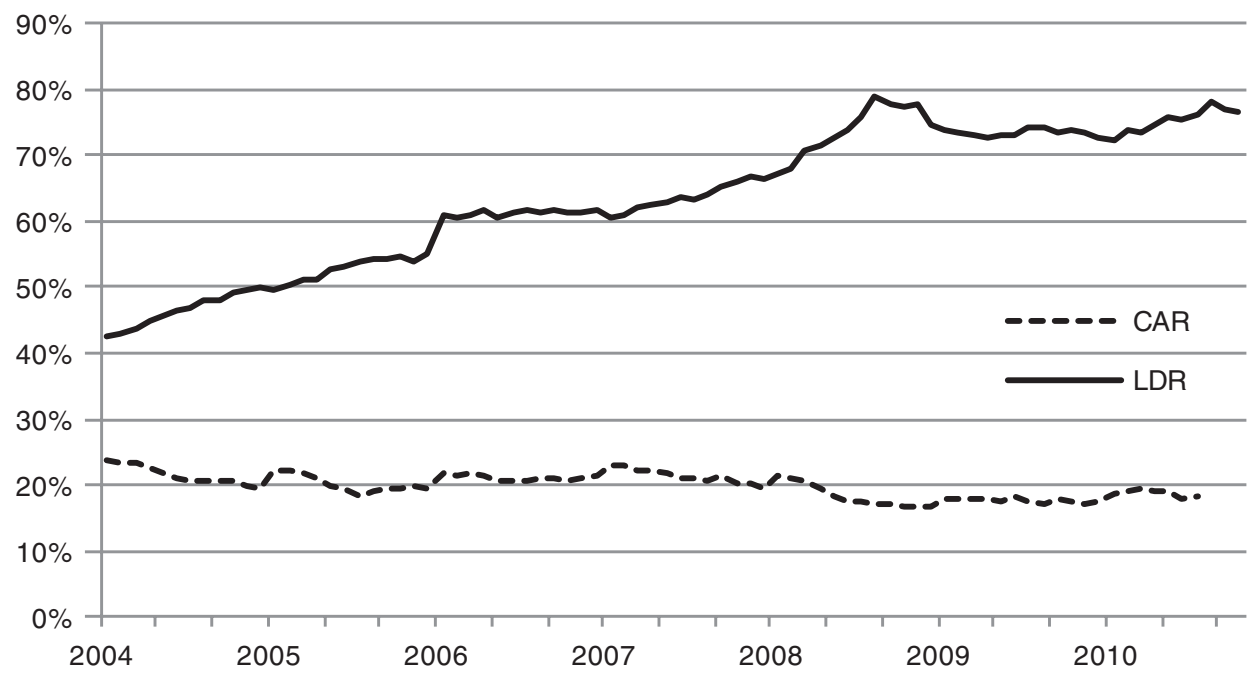

Figure 1 Loan to deposit ratios (LDRs) and capital adequacy ratios (CARs) for Indonesian commercial banks.

Source: Bank Indonesia.

\section{Unresponsive Supply of Financial Services}

Now is a wonderful time to own a bank in Indonesia. Banks are liquid, solvent, and profitable.

In contrast, now is not an opportune time to seek financing for your MSME. Hence the common refrain of Indonesian entrepreneurs: "If the banks are doing so well, why can't I get a loan?"

At first glance, it appears that BI has achieved its objective of improving the soundness of the banking sector without impinging on the intermediation mission of banks.

As shown in Figure 1, both liquidity and solvency are indeed very good: commercial banks have doubled their loan to deposit ratio (LDR) from a very low $40 \%$ to a prudent band between $70 \%$ and $80 \%$, and their capital adequacy ratio (CAR) has hovered around $20 \%$ since 2004 - this is $150 \%$ more than the $8 \%$ regulatory minimum and double the Basel III requirement of $10.5 \%$ in minimum total capital plus conservation buffer, effective in 2019. ${ }^{8}$ The stability of Indonesia's banking system can also be seen by its extremely high $z$-score, which was 12.2 at the end of 2009. In contrast, the US $z$-score was 2.3, while Thailand and Pakistan have $z$-scores of 5.3. Even Malaysia, often used as the benchmark for Southeast Asia, had a lower $z$-score at $8.0 .^{9}$

Consistent with a higher but not excessive LDR, credit has also expanded almost sixfold since 2002, as shown in Figure 2, implying that the banks are performing their intermediation function without fueling asset bubbles (see earlier macroeconomic indicators). NPLs have also declined to approximately 3\%, but reported NPLs should be viewed with caution in light of Bank Century's collapse after extended misrepresentation of its true financial condition to BI (Nasution, 2010). 


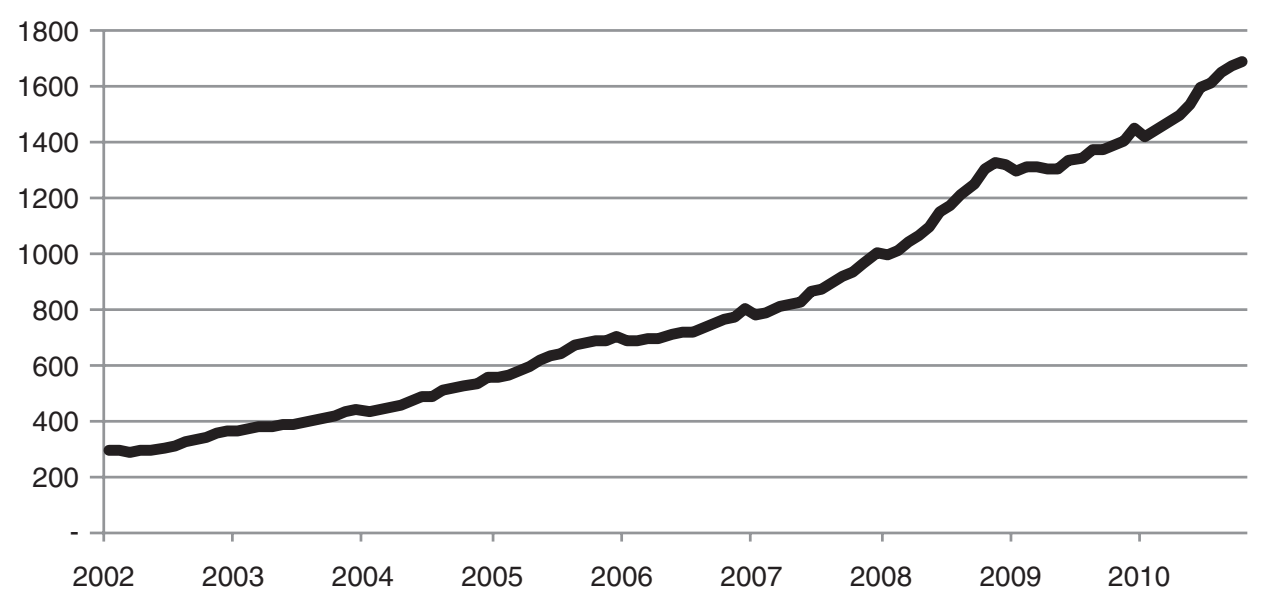

Figure 2 Rupiah and foreign exchange credit from commercial banks (bank umum) and Peoples Credit Bank (BPRs) in Indonesia; trillions of rupiah.

Source: Bank Indonesia.

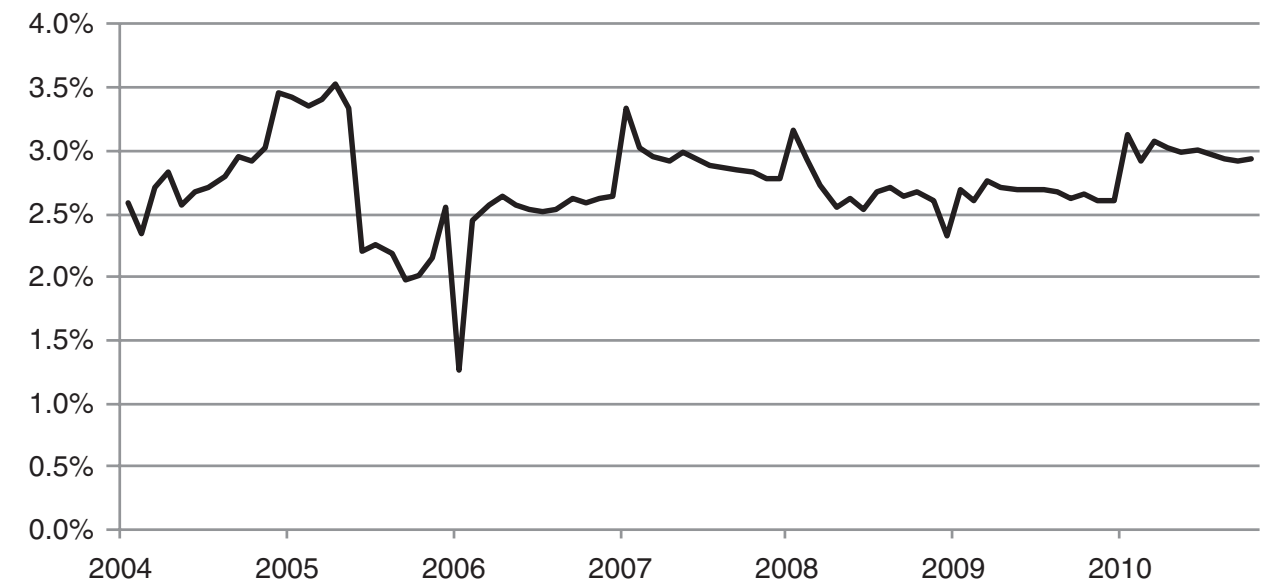

Figure 3 Return on assets for commercial banks (bank umum) in Indonesia.

Source: Bank Indonesia.

The banks are also quite profitable. As indicated in Figure 3, commercial bank return on assets has been between $2.5 \%$ and $3.5 \%$ since 2006, much higher than the conventional range of $1.0-1.5 \%$ of banks in the Philippines, Thailand, Malaysia, Singapore, and the USA.

But these aggregated figures are misleading and do not accurately reflect the MSME credit market today in Indonesia. For example, as shown in Table 3, two of the three largest banks have less than half of their assets in loans, and only two of the 10 largest banks have more than 70\% of their assets in loans; Bank Central Asia has one-fifth of its assets in BI certificates (SBIs), and Bank Mandiri has one quarter of its assets in government bonds. 


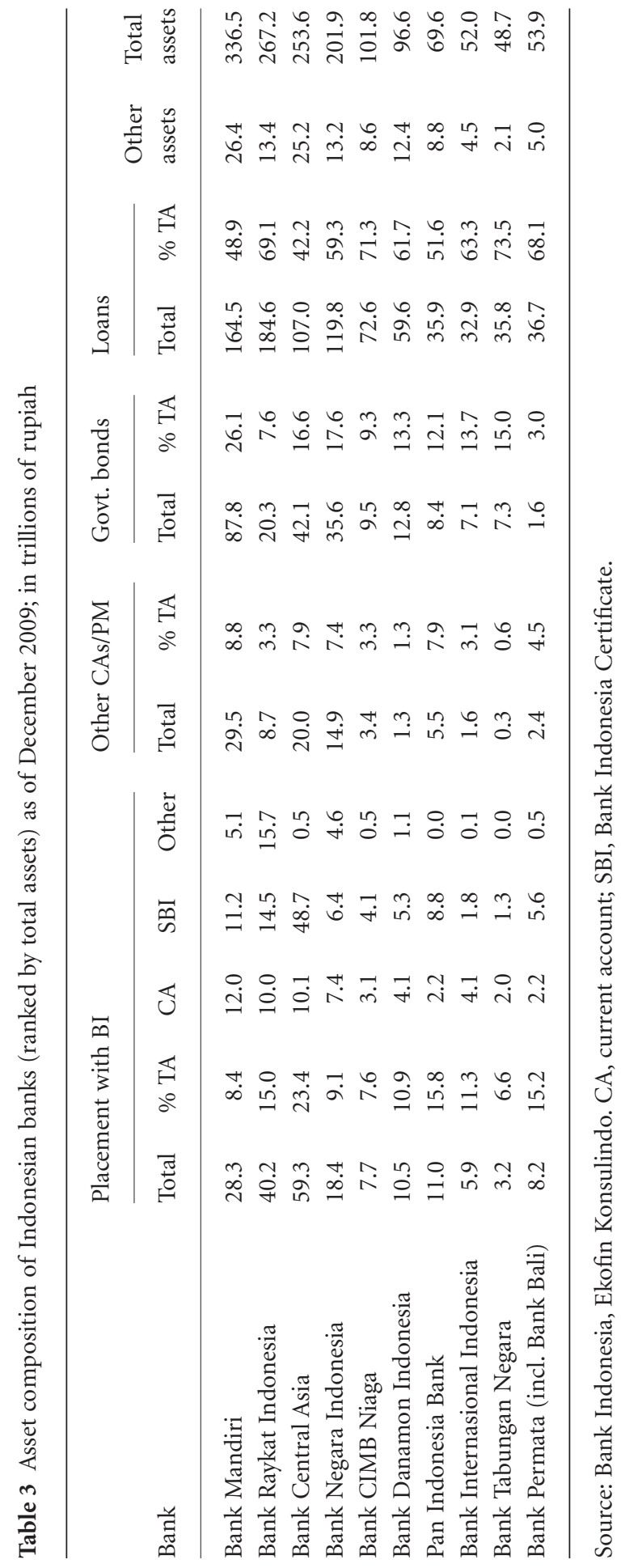




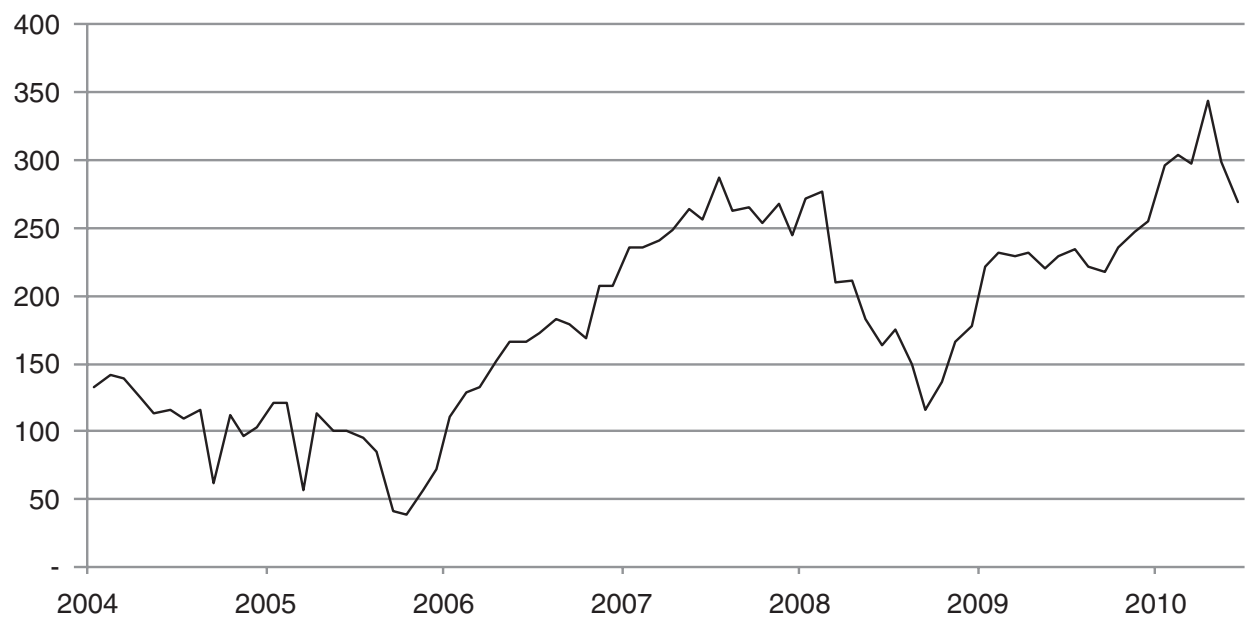

Figure 4 Total Sertifikat Bank Indonesia (SBIs); in trillions of rupiah. Source: Bank Indonesia Certificate.

Adjusting reserve requirements and issuing SBIs have been principal BI tools to control inflation, as indicated in Figure 4, and the banks have responded accordingly. BI demonstrated its intention to continue these practices when it increased the minimum reserve requirements of commercial banks in November 2010 from 5\% to 8\%. While this might be good for monetary policy and bank profitability, it has contributed to the crowding out of MSME access to credit. As discussed in Thee and Negara (2010), it also reflects a fundamental macroeconomic management contradiction, namely having costly and incompatible monetary and exchange rate policies - BI is trying to maintain a low inflation rate without allowing the rupiah to appreciate.

The disaggregation of bank income presented in Table 4 confirms the rationality of banks' responses to central bank incentives: given that most bank income still comes from interest earned, and that between one-fifth and one-third of interest income for six of the eight largest banks comes from investment interest rather than loan interest, the attraction of SBIs and government bonds to banks is clear, especially in light of the higher transaction costs and greater risk of MSME loans.

Although Indonesian banks have found it often more attractive to place their funds at other banks and to invest in government instruments than to make loans, total credit has nonetheless been growing at an annual rate of nearly 20\% (about 14\% in real terms) since 2002 (see Figure 2). Yet MSMEs claim they are finding it increasingly difficult to get loans for their businesses. Is there really a credit crunch? If so, why aren't large businesses equally affected?

Large businesses are different from MSMEs in terms of economic dominance and political influence. Large businesses mobilize themselves to ensure they have access to financing because they are few in number, rich in resources, and incentivized to lobby for benefits that are direct and concentrated. In contrast, MSMEs are much more difficult to 
Table 4 Interest income composition of Indonesian banks (ranked by total assets) as of September 2010; in trillions of rupiah

\begin{tabular}{|c|c|c|c|c|c|c|}
\hline \multirow{2}{*}{$\begin{array}{c}\text { Rank } \\
1\end{array}$} & \multirow{2}{*}{$\begin{array}{l}\text { Bank } \\
\text { Bank Mandiri }\end{array}$} & \multicolumn{2}{|c|}{ Loan interest } & \multicolumn{2}{|c|}{ Investment interest } & \multirow{2}{*}{$\begin{array}{l}\text { Total interest } \\
25.6\end{array}$} \\
\hline & & 18.0 & $70.3 \%$ & 7.6 & $29.7 \%$ & \\
\hline 2 & Bank Rakyat Indonesia & 24.4 & $88.4 \%$ & 3.2 & $11.6 \%$ & 27.6 \\
\hline 3 & Bank Central Asia & 9.8 & $66.2 \%$ & 5.0 & $33.8 \%$ & 14.8 \\
\hline 4 & Bank Negara Indonesia & 10.9 & $75.7 \%$ & 3.5 & $24.3 \%$ & 14.4 \\
\hline 5 & Bank CIMB Niaga & 8.0 & $88.9 \%$ & 1.0 & $11.1 \%$ & 9.0 \\
\hline 6 & Bank Danamon Indonesia & 8.0 & $75.5 \%$ & 2.6 & $24.5 \%$ & 10.6 \\
\hline 7 & Pan Indonesia Bank & 3.8 & $71.7 \%$ & 1.5 & $28.3 \%$ & 5.3 \\
\hline 8 & Bank Internasional Indonesia & 3.6 & $78.3 \%$ & 1.0 & $21.7 \%$ & 4.6 \\
\hline 9 & Bank Tabungan Negara & 4.1 & $91.1 \%$ & 0.4 & $8.9 \%$ & 4.5 \\
\hline 10 & Bank Permata (incl. Bank Bali) & na & na & na & na & na \\
\hline
\end{tabular}

Source: Financial reports of each bank listed.

organize as effective advocates for their businesses because they are an extremely large and diverse group for which the benefits of collective action would be diffuse and the potential for free riding considerable.

Large business lending is also different from MSME lending. Large business loans are conventional products that constitute the core business of banks, and thus are not likely to be affected much by the reregulation described in section 4. In contrast, MSMEs require the type of innovative products and delivery systems discouraged by Indonesia's reregulation policies.

These fundamental conceptual differences between large businesses and MSMEs are supported by quantitative data. The loan portfolios of many of Indonesia's largest banks are dominated by loans to large businesses and corporate clients, rather than loans to MSMEs. For example at the end of 2009, only $15 \%, 19 \%$, and $20 \%$ of the loan portfolios of Bank Mandiri, BCA, and Bank Negara Indonesia, respectively, were for MSMEs. ${ }^{10}$

Once again, however, aggregate figures do not tell the whole story. As indicated in Table 5, even though MSM (micro, medium, and small) credit (credit categorized by loan size and not by borrower) has indeed remained approximately half of all loans since 2005, further disaggregation of the data by loan use indicates that even credit reported as MSM loans, used in official documents as a proxy for MSME lending, greatly overstates support to MSMEs: consumption loans have consistently been half of all MSM credit and twothirds of micro and small loans. There has also been an upscaling of lending as micro loans and small-scale loans have switched positions in terms of their share of MSM credit: micro loans have dropped from $42.7 \%$ to $29.5 \%$ of MSM loans, while small-scale loans have grown from $27.5 \%$ to $41.2 \%$ of MSM loans.

However, the performance of two of the six largest banks, BRI and Bank Danamon, has been a notable exception to many of these trends, as virtually the entire portfolio of 


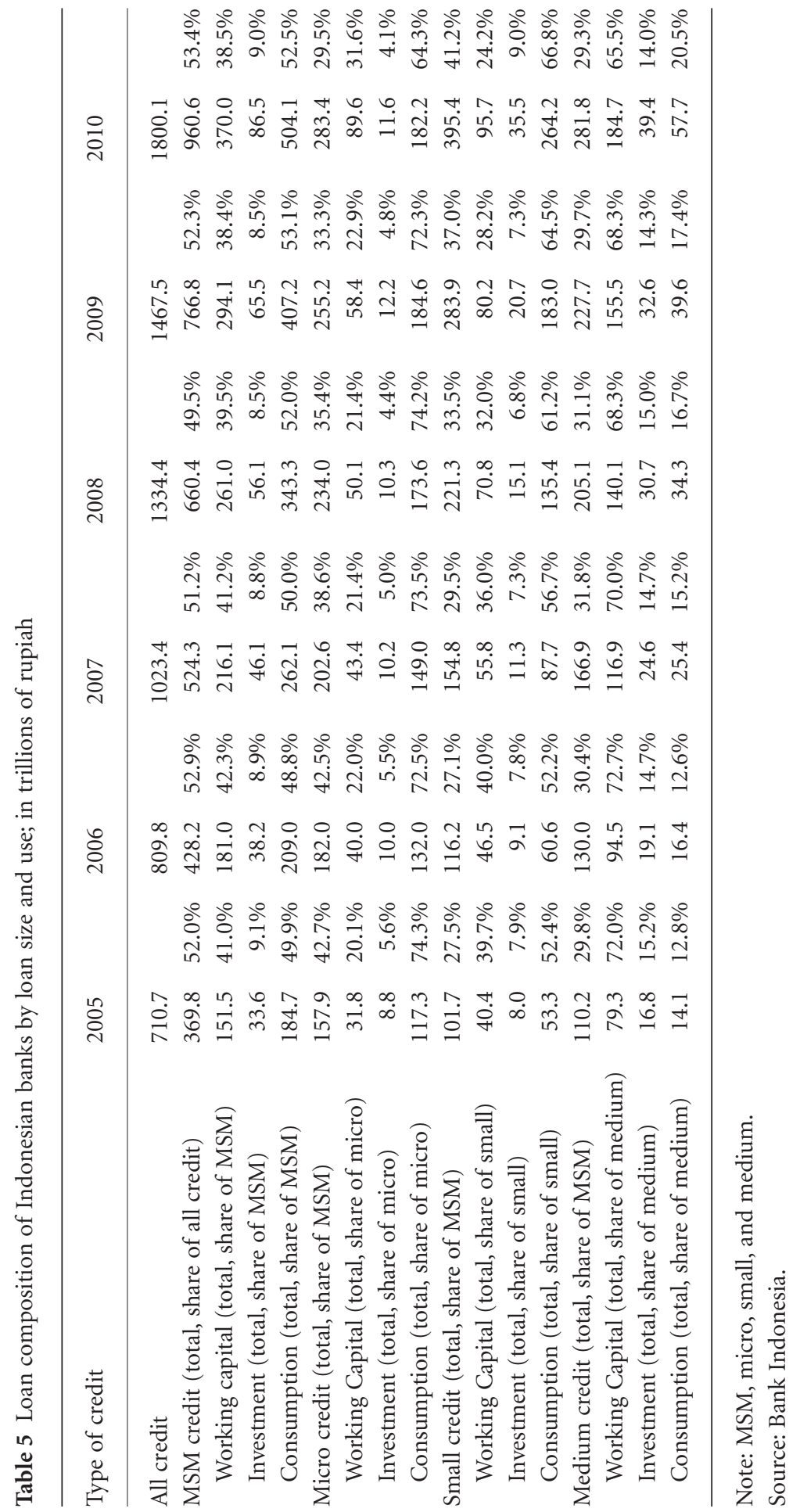


both banks is in MSME loans. Although many of these loans are consumer rather than enterprise finance, these two banks have nevertheless made extensive efforts to serve low-income households and family businesses.

Since BRI commercialized its micro-banking services in $1983,{ }^{11}$ it has dominated much of the micro-banking market in Indonesia, and in many places, it is still the sole formal financial institution. For example, the Rosengard et al. (2001) survey found that ${ }^{12}$

- More than half of the households with viable enterprises ${ }^{13}$ that had access to credit from a financial institution received loans exclusively from BRI units, and this number rose to two-thirds if it also included loans from a BRI unit and/or a BRI branch.

- Almost three-quarters of the households with viable enterprises that had access to savings services from financial institutions saved exclusively at BRI units, and this number rose to $85 \%$ if it also included savings at a BRI unit and/or a BRI branch.

The World Bank (2010) survey also found that BRI had the most extensive coverage in Indonesia: $40 \%$ of individuals with bank accounts had these accounts at BRI, and 23 of the 29 bank offices at the village level were BRI units. ${ }^{14}$

Table 6 provides a snapshot of BRI micro-banking services at the end of 2010, and the numbers are impressive by both national and international standards: 5.1 million microloans outstanding totaling Rp71.2 trillion, with NPLs comprising only $1.2 \%$ and an average loan size of just Rp14.0 million; 22.1 million savings accounts totaling Rp89.9 trillion, with an average account size of only Rp4.1 million; total micro-banking profits of Rp9.1 trillion; and an extensive distribution network of 4649 BRI units, all online, 617 BRI Teras (subunits), and 2437 automated teller machines (ATMs)at BRI units.

While breaking into micro-banking much later than BRI, since 2005, Bank Danamon has entered what it calls the "self-employed mass market" aggressively and has developed a large portfolio of microloans through its Danamon Simpan Pinjam (Danamon Savings and Loan), or DSP offices: at the end of September 2010, there were 1058 DSPs throughout Indonesia with 615,000 customers and loans outstanding of Rp14.4 trillion. ${ }^{15}$

Although Danamon had several unsuccessful attempts to break into this market in the past, the catalyst for this latest foray into MSME finance was a change in ownership in 2003 (Temasek Holdings of Singapore now owns 67.9\% of Danamon) and a subsequent reexamination of potential market opportunities in light of the competitive strengths and weaknesses of Indonesia's other large banks. This initiative is still seen as an experiment within Danamon, and so is under careful scrutiny and is accompanied by considerable internal debate on its future prospects.

\section{Disabling Regulatory Context and Perverse Incentives}

Despite the continued impressive performance of BRI in micro-banking and the encouraging entry of Danamon into this market, BI's regulatory policies since the 1997 East Asian crisis have created fundamental internal problems for BRI's micro-banking operations, significantly reduced innovation and outreach for financial institutions that serve the economic stratum below the micro-banking market of commercial banks, and generated strong disincentives for other financial institutions to enter both the micro-finance 


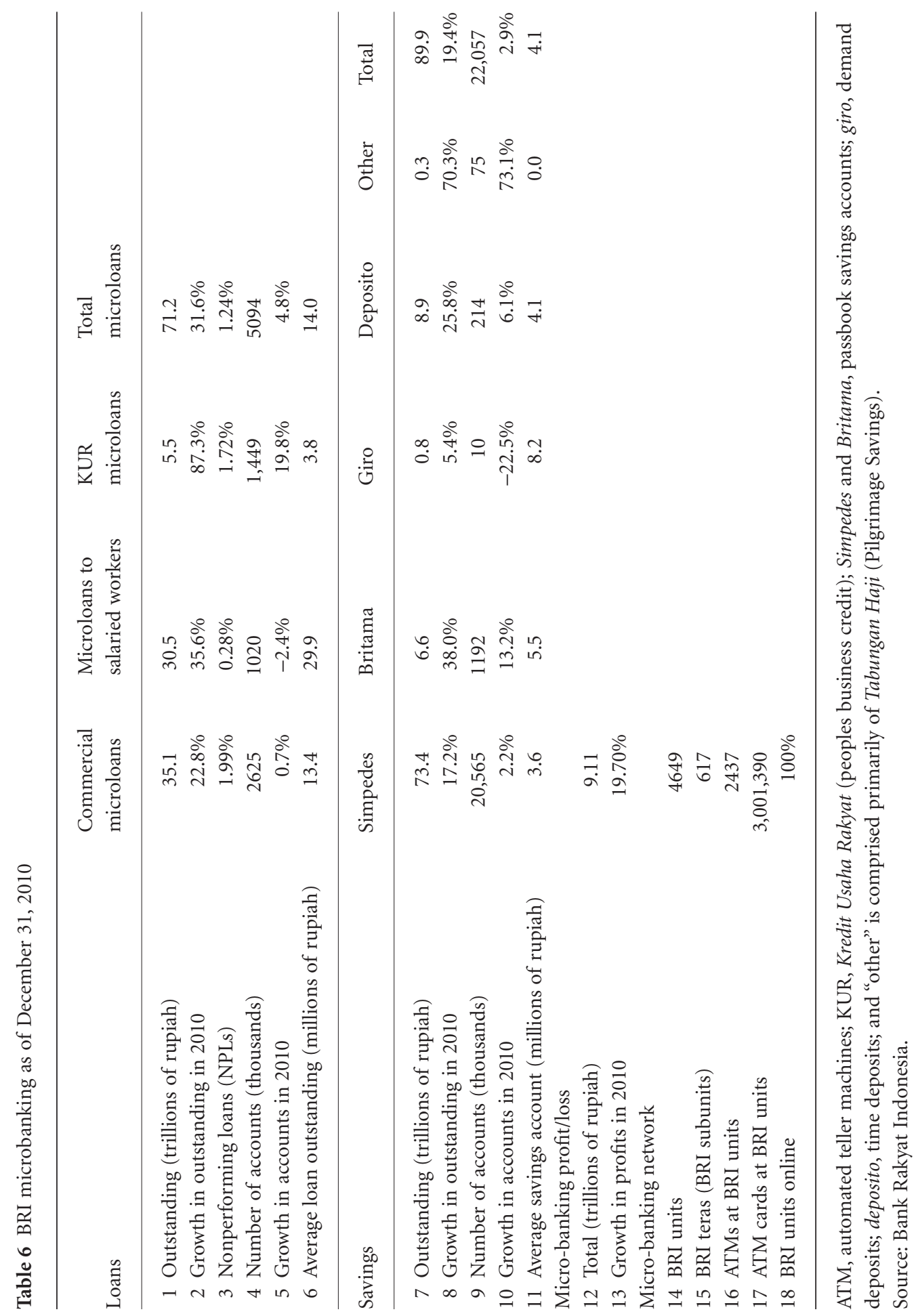


and SME markets. These unintended consequences of BI's postcrisis regulatory regime are in addition to the detrimental impact of BI's monetary policies on MSME finance discussed in the previous section.

The 1997 crisis, dubbed Krismon (Krises Moneter, Monetary Crisis) in Indonesia, was both traumatic and expensive: it destroyed the country's banking system, and the cost of recapitalizing Indonesia's banks totaled 70\% of 1999 GDP (Rosengard, 2002).

Thus, BI's principal objective after Krismon was to ensure that such a collapse would not happen again. Under its Arsitektur Perbankan Indonesia (API, Indonesia Banking Architecture) program, BI has pushed for a consolidation of its banking sector in the belief that an administratively determined small number of large, full-service commercial banks would be safer than a broader and more diverse banking sector resulting from openmarket competition. BI has also allowed the continued operation of numerous Bank Perkreditan Rakya (BPRs) or Peoples Credit Bank, but these are special license banks with a very restricted scope of operation (Bank Indonesia, 2005a). Thus, as indicated in Table 2, although the number of bank branches has almost doubled and number of bank ATMs has tripled since Krismon, the number of all types of banks has declined considerably since 1997.

As noted in section 3, government recapitalization of the banking sector and BI's subsequent API have resulted in banks that are predominantly liquid, solvent, and profitable. Indonesia's prudentially sound banking sector also shielded it from most of the direct impacts of the current global economic crisis, so BI feels vindicated in its regulatory policies (Bank Indonesia, 2010b).

But these policies have also created what the World Bank and International Finance Corporation (2009) describe as a "medium concentration oligopoly": "oligopoly" because whether in terms of assets, credit outstanding, or third-party funds, approximately half of the banking system's total is held by the five largest banks, two-thirds by the 10 largest banks, and four-fifths by the 20 largest banks (Table 7); "medium concentration" because no single bank has greater than a $15 \%$ share, and only three banks have greater than a $10 \%$ share.

Nevertheless, an oligopoly is still an oligopoly, regardless of degree of concentration, and by definition, provides opportunities for collusion in pursuit of greater profits. There are several indications that this consolidated banking structure has indeed generated an acute failure of competition that has fostered an inefficient, rent-seeking oligopoly. ${ }^{16}$

For example, according to BI Governor Darmin Nasution, the average operating ratio (operating cost to operating income) and net interest margin (NIM) of Indonesian banks are $82 \%$ and $6 \%$, respectively, while the operating ratio and NIM of banks in neighboring countries are from $33 \%$ to $73 \%$ and $2 \%$ to $5 \%$, respectively (Samboh, 2011). This is confirmed by the data presented in Table 8 .

Thee and Negara (2010; p. 301) believe that Indonesia has the highest NIM in this ASEAN comparison mainly because of inefficient provincial and state bank management, as these banks have NIMs of $9.0 \%$ and $6.3 \%$, respectively; in contrast, the NIM of private domestic foreign exchange banks is $5.3 \%$, joint banks $3.8 \%$, and foreign banks $3.5 \%$. Nonetheless, all of these NIMs are still relatively high, and the NIMs of Indonesian 
Table 7 Indonesia's banking oligopoly

\begin{tabular}{llll}
\hline $\begin{array}{l}\text { Bank concentration } \\
\text { metric }\end{array}$ & $2008(\%)$ & $2009(\%)$ & Change (\%) \\
\hline $\begin{array}{l}\text { Total assets } \\
5 \text { largest banks }\end{array}$ & 50.0 & 51.6 & 3.3 \\
10 largest banks & 64.1 & 65.4 & 2.0 \\
20 largest banks & 79.0 & 79.5 & 0.6 \\
Total credit outstanding & & & \\
5 largest banks & 47.3 & 49.1 & 3.8 \\
10 largest banks & 62.9 & 64.5 & 0.5 \\
20 largest banks & 78.4 & 78.8 & \\
Total third party funds & & & 3.7 \\
5 largest banks & 51.6 & 53.5 & 4.0 \\
10 largest banks & 63.4 & 66.0 & 3.4 \\
20 largest banks & 77.0 & 79.6 & \\
\hline
\end{tabular}

Source: Authors' calculations from data in Bank Indonesia (2010a).

Table 8 Efficiency of banks in ASEAN

\begin{tabular}{lll}
\hline Country & $\begin{array}{l}\text { NIM (\%) } \\
2009\end{array}$ & $\begin{array}{l}\text { Operating ratio (\%) } \\
2006\end{array}$ \\
\hline Indonesia & 5.9 & 73.9 \\
Philippines & 3.9 & 71.7 \\
Thailand & 3.4 & 66.4 \\
Vietnam & 3.4 & 49.2 \\
Malaysia & 3.0 & 49.6 \\
Singapore & 1.8 & 45.1 \\
\hline
\end{tabular}

Source: Thee and Negara (2010) for NIM; BankScope and Infobank Research Bureau for Operating Ratio.

domestic banks are even higher, whether large foreign exchange banks at 5.3\% or small nonforeign exchange banks at $9.5 \% .{ }^{17}$

The picture becomes more disconcerting when bank spreads are disaggregated by loan product. Keeping in mind Indonesia's low inflation rate and concomitant low cost of funds, as well as the banks' reliance on consumer finance, the interest rates show in Table 9 appear to be exorbitant, ranging from $2.7 \%$ to $4.5 \%$ per month, regardless of bank ownership (state, private, foreign).

Another possible indicator of failure of competition in Indonesia's banking sector is the extremely high price to earnings ratio (PER) ${ }^{18}$ of the 10 largest banks. Table 10 shows 
Table 9 Credit card monthly interest rates for Indonesian banks in June 2009

\begin{tabular}{ll}
\hline Bank & Interest rate (\% monthly) \\
\hline Bank Rakyat Indonesia & 2.7 \\
Bank Negara Indonesia & 3.0 \\
Bank Mandiri & 3.5 \\
Bank Bukopin & 3.5 \\
Bank Permata & 4.5 \\
Bank Central Asia & 3.3 \\
Bank UOB Buana & 3.5 \\
Citibank & 3.5 \\
HSBC & 3.3 \\
\hline
\end{tabular}

Note: These rates are indicative rather than directly comparable because the specifics of each bank's credit card facilities differ.

Source: Infobank Special Edition 2009.

Table 10 Price/Earnings Ratios for Indonesian banks in 2010

\begin{tabular}{rlll}
\hline Rank & Bank & PER Q3-2010 & PER annualized \\
\hline 1 & Bank Mandiri & 19.9 & 14.9 \\
2 & Bank Rakyat Indonesia & 19.4 & 14.6 \\
3 & Bank Central Asia & 23.5 & 17.6 \\
4 & Bank Negara Indonesia & 18.1 & 13.6 \\
5 & Bank CIMB Niaga & 23.7 & 17.8 \\
6 & Bank Danamon Indonesia & 23.1 & 17.3 \\
7 & Pan Indonesia Bank & 23.5 & 17.6 \\
8 & Bank Internasional Indonesia & 83.8 & 62.8 \\
9 & Bank Tabungan Negara & 20.7 & 15.5 \\
10 & Bank Permata (incl. Bank Bali) & 16.5 & 12.4 \\
\hline
\end{tabular}

Source: Financial statements of each bank, calculated by Indonesia Finance Today (IFT) Research Department.

PER, price to earnings ratio.

that most of the annualized PERs for 2010 are from 14\% to 18\%, almost double the global banking industry standard of between $8 \%$ and 10\%. High PERs reflect market expectations of significant growth prospects, but it is unclear whether this is because shareholders perceive competitive advantages or because they expect to profit from the continued reaping of monopoly rents. ${ }^{19}$

Two other indicators of lack of competition in Indonesia's banking system are API's barriers to entry and exit. Senior BI officials have conceded that it is virtually impossible 
to establish a new bank in Indonesia unless one buys the banking license of an existing bank. ${ }^{20}$ It is also quite difficult to fail: BI has closed just one bank in the last 5 years when it revoked the business license of Bank IFI in April 2009 (BI Governor Decree no. 11/19/ KEP.GBI/2009). ${ }^{21}$ This creates a comfortable environment for existing large banks to exploit their market domination at the expense of potential competitors. It also presents BI with yet another unanticipated dilemma: the largest banks are now both too big to regulate and too big to fail. Moreover, Demirgüç-Kunt and Huizinga (2011) have found that "systemic size is an unmitigated bad" because systemically large banks reduce return without lowering risk, and are often too big to save.

In addition to creating an inefficient, rent-seeking oligopoly, BI's API has greatly concentrated credit risk. Today, most Indonesian banks look alike, offering the same products at the same prices in the same locations to the same markets. Not only does this increase rather than mitigate systemic risk, but it also exacerbates the exclusionary nature of Indonesia's banking system.

As described in detail in Rosengard et al. (2007), this phenomenon can be seen most clearly in the impact of BI's regulatory regime on two types of MFIs that serve primarily rural and semi-urban markets: village-owned microfinance institutions (VMFIs) operating exclusively at the village (desa) level, and local government-owned microfinance institutions (GMFIs) operating at the subdistrict (kecamatan) and village (desa) levels. ${ }^{22}$

VMFIs were Indonesia's original MFIs established in the 1890s as village banks (bank desa) and village paddy banks (lumbung desa) to provide savings and credit facilities for villages in Java and Madura. VMFIs are owned and operated by the villagers they serve, now under the technical supervision of BRI on behalf of BI. There is no conflict of interest with the BRI units because BRI unit coverage does not extend to the village level. VMFI clients are also much poorer than BRI unit customers: at the end of May 2003, the 4518 active VMFIs had Rp186.8 billion in loans outstanding to 438,938 borrowers, with an average loan size of Rp426,000; they also had 524,671 savers with Rp35.3 billion in savings, for an average savings account of Rp67,000. VMFI loan interest rates are roughly double those of the BRI units, and their loans are usually for 12 weeks with weekly payments, as opposed to 1-2 year loans with monthly installments at the BRI units.

GMFIs were modeled after the VMFIs to serve villages without VMFIs. Established by about a third of Indonesia's provincial governments, GMFIs are autonomous nonbank financial institutions headquartered at the subdistrict level that send motorcycle teams to villages on traditional market days. Their products and pricing are similar to VMFIs.

A combination of the 1992 Banking Law ${ }^{23}$ and API have frozen the development of VMFIs, and compelled many GMFIs to consolidate operations at higher levels of government and to favor payroll deduction loans for salaried workers over business loans to microenterprises. Both the 1992 Banking Law and API treat VMFIs and GMFIs as BPRs despite their very different products, clients, and service areas. Thus, although badan kredit desa (BKDs) were granted a collective BPR license and exempted from some BPR regulatory requirements, ${ }^{24}$ the status of VMFIs is still unclear, especially regarding their savings mobilization activities. GMFIs are supposed to convert to BPRs, meaning they 
must meet minimum capital requirements that greatly exceed their needs and follow operational norms that undercut their effectiveness as MFIs since BI treats BPRs essentially as small commercial banks. Roughly one-quarter of GMFIs have converted to BPRs (or other permitted institutions such as cooperatives), ${ }^{25}$ while the remainder have either closed or continue to operate with ambiguous legal status.

The consequence for GMFIs is to try to look like other banks so they: (i) consolidate at the district or provincial level in the spirit that larger banks are better banks; (ii) offer traditional loan products like payroll deduction loans to salaried workers, because the regulator knows and understands these credit products; and (iii) close village posts for expediency to accommodate the first two operational changes. As BPRs, they also come under the direct supervision of BI, which greatly undermines and sometimes completely severs provincial government oversight and technical support. This is not the objective of BI's regulatory regime, but BI is largely unaware of these unintended consequences; the decrease in microenterprise lending is not evident because loans are reported to BI by loan size, not loan use or client, and the closing of village posts, which are classified as subbranch offices, is not tracked in BI aggregated statistics.

Just as BI's well-intentioned policies to strengthen the banking system have decreased innovation and access for village-level microfinance services, its equally well-intentioned policies to force commercial banks to lend more to MSMEs have also been counterproductive. BI has essentially restored several components of the financial repression it had phased out with the comprehensive banking reform of the $1980 \mathrm{~s}^{26}$ and the BI reform of Law no. 23/1999. ${ }^{27}$

When Indonesia liberalized and deregulated its banking system, removing interest rate ceilings, credit allocation requirements, controls on expansion of branch networks, and barriers to entry, it ended most of its directed lending. The main exception to this was special "program credit" by which BI funneled its money (likuiditas BI) through commercial banks for priority sectors such as MSMEs. These were subsidized credit programs, and the banks served as channeling rather than executing institutions so they bore little, if any, of the credit risk for these loans.

Under the postcrisis central banking law, BI is no longer allowed to implement such programs. Instead, it is supposed to focus entirely on monetary policy - even banking supervision is to be moved to a new regulatory agency, the Financial Services Authority (Otoritas Jasa Keuangan). ${ }^{28}$

Nonetheless, the government, via Ministry of Finance regulations, is trying to get BI to indirectly dictate which banks should lend to, and at what price, through programs such as Kredit Usaha Rakyat, Peoples Business Credit (KUR). ${ }^{29}$ Kredit Usaha Kecil, Small Business Credit (KUK) is reminiscent of BI's KUK program of the 1990s under which all banks were required to lend $20 \%$ of their total credit to microenterprises. KUK was fatally flawed conceptually and a dismal failure operationally: many banks had no internal mandate, desire, or expertise to engage in MSME finance, so were extremely creative in both "representing" their loan portfolios so they appeared to be in compliance with KUK requirements and in channeling KUK loans through other financial institutions. Although KUR does not have specific credit allocation quotas, KUR loans are to be made to "feasible 
but not bankable" enterprises (i.e. profitable enterprises without previous access to credit) at below market rates and with partial external loan guarantees. ${ }^{30}$

The government's moral suasion has not been very effective in compelling private banks with successful market-based MSME credit facilities such as Danamon to engage in KUR lending, but it has created challenges for state banks with such products, such as BRI. It places BRI in the untenable position of being forced to offer the same loan product at the same location to the same clientele at two different prices. Not only does this appear to be inequitable, as the lower interest rates are only for new borrowers, but it undermines the commercial sustainability of micro-banking operations and offers opportunities for corruption through interest rate arbitrage.

Furthermore, BI will require commercial banks to increase their LDRs to between 78\% and $100 \%$ by March 2011, and will impose higher minimum reserve requirements on banks whose LDR is not within this range. ${ }^{31}$ If the banks comply, they could increase credit without lending more to MSMEs, potentially fueling speculative asset bubbles like in the mid-1990s or overcrediting consumers as Korean banks did in the aftermath of the East Asian crisis. If the banks do not comply, it will simply increase their cost of lending. Either way, it is unlikely this will meet BI's primary objective of encouraging more loans to MSMEs.

Other examples of government intervention in the credit allocation decisions of banks is the Ministry of State-Owned Enterprises' PKBL (Program Kemitraan Badan Usaha Milik Negara dengan Usaha Kecil dan Program Bina Lingkungan, SOE-Small Enterprise Partnership Program and Environmental Protection Program) ${ }^{32}$ and BI's new MSME Business Plan regulation. ${ }^{33}$ Under PKBL, all SOEs must allocate $4 \%$ of after-tax profits to MSME credit and environmental protection programs as part of their corporate social responsibility requirements with many restrictions on the credit component of PKBL. Under the MSME regulation, all banks must submit to BI a plan for MSME lending by sector, province, and credit scheme.

\section{Deregulation, Reregulation, and Smart Regulation}

In the 1980s, Indonesia deregulated its banking system faster than it developed the technical capacity and political will to oversee banks with newly acquired freedom. It paid dearly for this mistake with Krismon in the late 1990s. Indonesia responded by reregulating its banking system after the crisis with the introduction of API, including an administratively imposed freeze on the establishment of new banks and consolidation of existing banks, as well as a return to directed lending. This has resulted in prudentially sound but inefficient and noninclusive banks. Today's challenge is to find a balance between these two approaches.

The government is convinced that banking reform by administrative fiat will produce faster results at a lower risk than waiting for behavioral change spurred by market-based incentives. Thus, with each disappointing outcome, the government issues an even stronger directive to force banks to lend to MSMEs: from the moral suasion of KUR, to the required preparation of detailed MSME business plans, to the mandatory higher LDRs and threat of greater minimum reserve requirements for noncompliance. This approach is 
a great stride backwards for Indonesia, as the only thing more repressive than directed credit with central bank funds is directed credit with third party deposits.

Section 2 demonstrates that there clearly is an unmet effective demand from MSMEs for financing facilities, and section 3 shows that most commercial banks certainly have not taken advantage of this market opportunity. But bank behavior has been a rationale, albeit undesired, response to the current regulatory environment that is detailed in section 4 and summarized below:

- The government strengthened Indonesia's commercial banking oligopoly with the introduction of API, erecting effective barriers to competition: no new banks, consolidation of existing banks, and forbearance in dealing with failing banks.

- The government also weakened incentives for innovation and outreach at the micro-banking level and concentrated credit risk by homogenizing the banking system: mandatory VMFI and GMFI conversion to BPR, weakening or severance of provincial government oversight and technical support, centralization of operations, and preference for standard loan products and delivery systems.

- The government concurrently pursued monetary policies that reduced loanable funds at the disposal of banks and provided investment opportunities for this reduced pool of funds that were more attractive to banks than making loans: high minimum reserve requirements coupled with issuance of government bonds and SBIs.

- Amid concerns of financial exclusion, the government also instituted several measures that reverted to past practices of directed lending: KUR, PKBL, and MSME plans.

- Still unsatisfied with the banking sector's response, the government mandated higher LDRs but continued to pursue a contradictory monetary policy by also raising minimum reserve requirements to fight inflation.

Government recognition that the unintended consequences of its own banking sector reregulation have created perverse incentives for banks to avoid MSME financing is also the key to addressing this problem. While the government might still wish to use its control over banking system liquidity to manage money supply despite the drawbacks if alternative instruments are ineffective, it can still create powerful incentives for banks to explore new markets such as MSME lending: it can remove barriers to commercial banking competition to provide a catalyst for SME lending, and it can recognize the need for nonbank financial institutions such as VMFIs and GMFIs for micro-banking and adapt its regulatory regime accordingly.

Indonesia should not respond to financial exclusion by artificially pumping out and administratively allocating more credit. Instead, it should promulgate smart regulation so that banks maintain their sound risk management without pursuing noncompetitive and noninclusive business practices. The fundamental problem today is not a slow rate of credit growth, but rather, concentrated composition of lending; increasing the aggregate level of financial intermediation is a longer term challenge best pursued incrementally.

However, even if the government makes these changes, there is still a significant constraint to MSME lending because of the perceived high risks and low returns of MSME finance. Conventional commercial bankers should indeed be wary of a potentially high level of NPLs and unsustainable transaction costs in the MSME sector unless they truly 
understand how to serve this market - there is certainly increased likelihood of both default resulting from ineffective risk assessment and risk mitigation practices, coupled with significant cost overruns from inappropriate loan products and delivery systems. Banks often treat MSME loans simply as smaller versions of large loans despite the very different characteristics of MSMEs and the requisite financial model needed to make serving this market profitable. Slow, centralized decision making based on extensive analysis of financial statements and industry-wide data for a handful of long-term loans must be replaced by quick, decentralized decision-making based on cash flow analysis and character assessment for a much larger volume of shorter term loans.

Until banks have a viable model for financing MSMEs, they should continue to approach this market with great caution despite government prodding, especially if they have attractive alternative uses of their funds such as those described above. But only competitive pressures to develop new markets provide sufficient incentives for banks to figure out how to serve MSMEs in a commercially sustainable way, and forcing banks to act against their fiduciary responsibilities to their owners and depositors is rash and counterproductive.

\section{Notes}

1 The Financial Structure Dataset (FSD) was first published in 1999 and presented in both Beck et al. (2000) and Demirgüç-Kunt and Levine (2001). The complete, updated FSD is available, together with detailed explanations of all terms and sources used in the FSD at: http://siteresources.worldbank.org/INTRES/Resources/469232-1107449512766/FinStructure_ 2009.xls

2 The IMF's Financial Access Survey is available by individual country and in cross-country format at: http://fas.imf.org/

3 Three thousand three hundred sixty households were surveyed using multistage random sampling with population-weighted selection at each stage. The survey methodology is described in detail in Annex B of World Bank (2010).

4 World Bank (2010; pp. 13, 50-55).

5 World Bank (2010; pp. 55-77). Also, see Annex A for a discussion of "access" versus "use," as well as of "voluntary" versus "involuntary" exclusion." Despite these distinctions, the World Bank still relies on "use" as a proxy for access at prevailing prices throughout its report, since it is difficult in practice to distinguish between voluntary and involuntary exclusion.

6 According to Republic of Indonesia (2008), the Government of Indonesia defines MSMEs based on net assets or annual turnover: a microenterprise has net assets $\leq$ Rp50 million or annual turnover $\leq$ Rp300 million; a small enterprise has net assets $>$ Rp50 million but $\leq$ Rp500 million or annual turnover $>\mathrm{Rp} 300$ million but $\leq \mathrm{Rp} 2.5$ billion; and a medium enterprise has net assets $>\mathrm{Rp} 500$ million but $\leq \mathrm{Rp} 10$ billion or annual turnover $>\mathrm{Rp} 2.5$ billion but $\leq \mathrm{Rp} 50$ billion. In contrast, according to World Bank (2010, ft. 105), BI defines MSMEs based on loan size: a microloan is $\leq \mathrm{Rp} 50$ million; a small loan is $>\mathrm{Rp} 50$ million but $\leq \mathrm{Rp} 500$ million; and a medium loan is $>\mathrm{Rp} 500$ million but $\leq \mathrm{Rp} 5$ billion. We use BI definitions when analyzing bank lending by loan size.

7 The exchange rate used throughout this paper is Rp9,000 $=$ US\$1.00. 
8 See Basel Committee on Banking Supervision (2010) for a detailed explanation of new capital, leverage, and liquidity requirements, as well as phase-in arrangements and scheduled transition periods.

9 See the World Bank's FSD for a complete listing of $z$-scores. According to Beck et al. (2009; p. 9), "The z-score [emphasis in original text] is the ratio of return on assets plus capital-asset-ratio to the standard deviation of return on assets. If profits are assumed to follow a normal distribution, it can be shown that the $\mathrm{z}$-score is the inverse of the probability of insolvency. Specifically, $\mathrm{z}$ indicates the number of standard deviations that a bank's return on assets has to drop below its expected value before equity is depleted and the bank is insolvent... Thus, a higher z-score indicates that the bank is more stable."

10 Data compiled by Bank Indonesia and Ekofin Konsulindo.

11 See Patten and Rosengard (1991) for a detailed account of the commercialization of BRI's micro-banking services.

12 Rosengard et al. (2001; table 12).

13 A "viable enterprise" is an enterprise that would qualify for a BRI unit loan according to the enumerator, who was either a BRI unit manager (kaunit) or BRI unit loan officer (mantri).

14 World Bank (2010; p. 50).

15 Figures from Ali Yong, Director of Credit, Bank Danamon.

16 See The Economist (2010) for a summary of what it describes as the "profits puzzle" of Indonesian banks.

17 All figures used in this NIM disaggregation are from July 2010; the total for all banks is 5.8.

18 PER is calculated as the ratio of the market price per share to the earnings per share. In Asia the denominator (earnings) is "trailing" so is the actual earnings of the previous four quarters, while the numerator (price) is a market-based expectation of future profitability.

19 In contrast, low PERs indicate a risk premium for potential future instability or declining competitiveness.

20 This conclusion is based on both plentiful anecdotal data and extensive discussions the authors held with senior BI officials in January 2011.

21 Even this closure was quite late and relatively insignificant, as Bank IFI had been under BI intensive supervision since 2002 and when closed, its total assets were $0.01 \%$ of total banking assets (http://cpns.beasiswaz.com/bank-ifi).

22 Most GMFIs are referred to as LDKPs (lembaga dana kredit pedesaan, village credit institutions) and most VMFIs are called BKDs (badan kredit desa, village credit bodies).

23 Law 7/1992 on Banking.

24 World Bank (2010; box 14).

25 World Bank (2010; box 14).

26 See McLeod (1996) for a detailed account of banking deregulation in Indonesia. See Patten and Rosengard (1991) and Charitonenko and Afwan (2003) for the impact of banking deregulation on the development of micro-banking in Indonesia.

27 Amended by Law no. 3/2004 and Law no. 6/2009.

28 See McLeod (2011) for a discussion of the uncertainty that this will ever happen, and the pitfalls if it does.

29 Ministry of Finance Regulations no. 135/PMK.05/2008 and no. 189/PMK.05/2010 on the Micro Credit Guarantee Facility.

30 At present, interest rates are $\leq 22 \%$ for loans $<$ Rp 20 million and $\leq 14 \%$ for loans from Rp20 million to Rp500 million, versus current market rates of roughly $33-90 \%$ and $17-18 \%$, 
respectively; guarantees are from $70 \%$ to $80 \%$ of the loan, depending on sector and borrower (e.g. higher percentage for overseas workers and agriculture).

31 Thee and Negara (2010, p. 296); Manurung and Ahlstrand (2010).

32 Ministry of State-Owned Enterprises Regulation No. PER-05/MBU/2007.

33 Bank Indonesia Regulation no. 12/21/PBI/2010.

\section{References}

Agung J., Kusmiarso B., Pramono B., Hutapea E.G., Prasmuko A. \& Prastowo N.J. (2001). Credit Crunch in Indonesia in the Aftermath of the Crisis: Facts, Causes and Policy Implications. Jakarta: Directorate of Economic Research and Monetary Policy, Bank Indonesia.

Bank Indonesia (2005a). Arsitektur Perbankan Indonesia [Indonesian Banking Architecture]. Jakarta: Bank Indonesia.

Bank Indonesia (2005b). Results of Study of Micro, Small and Medium Businesses (MSMEs) Profile. Jakarta: Bank Indonesia.

Bank Indonesia (2010a). Indonesia Banking Directory 11, September.

Bank Indonesia (2010b). Krisis Global dan Penyelamatan Sistem Perbankan Indonesia [The Global Crisis and the Safety of Indonesia's Banking System]. Jakarta: Bank Indonesia.

Basel Committee on Banking Supervision (2010). Basel III: A Global Regulatory Framework for More Resilient Banks and Banking Systems. Basel, Switzerland: Bank for International Settlements.

Beck T. \& Al-Hussainy E. (2010). Financial Structure Dataset. Washington, DC: World Bank.

Beck T., Demirgüç-Kunt A. \& Levine R. (2000). A new database on financial development and structure. World Bank Economic Review, 14 (3), 597-605.

Beck T., Demirgüç-Kunt A. \& Levine R. (2009). Financial institutions and markets across countries and over time: Data and analysis. World Bank Policy Research Working Paper no. 4943. Washington, D.C.: World Bank.

Charitonenko S. \& Afwan I. (2003). Commercialization of Microfinance: Indonesia. Manila: Asian Development Bank.

Demirgüç-Kunt A. \& Huizinga H. (2011). Do we need big banks? Evidence on performance, strategy and market discipline. World Bank Policy Research Working Paper no. 5576. Washington, D.C.: World Bank.

Demirgüç-Kunt A. \& Levine R. (2001). Bank-based and market-based financial systems: Cross country comparisons. In: Demirgüç-Kunt A. \& Levine R. (eds), Financial Structure and Economic Growth: A Cross-Country Comparison of Banks, Markets, and Development, 2001. Cambridge, MA: MIT Press, 81-140.

International Monetary Fund (IMF) (2010). Financial access Survey. Washington, DC: IMF.

Johnston D. \& Morduch J. (2008). The unbanked: Evidence from Indonesia. The World Bank Economic Review, 22 (3), 517-537.

Manurung N. \& Ahlstrand G. (2010). Bank Indonesia prefers tightening rules for lenders over rate hike. The Jakarta Globe, September 7.

McLeod R. (1996). Control and competition: Banking deregulation and re-regulation in Indonesia. Economics RSPAS Working Paper no. 1996-07. Canberra: ANU.

McLeod R. (2011). Survey of recent developments. Bulletin of Indonesian Economic Studies, 47 (1), $7-34$.

Nasution A. (2010). Berbagai kelemahan penanganan PT Bank Century tahun 2004-2008 [Various weaknesses in the handling of Bank Century during 2004-2008]. Unpublished paper, Jakarta, 15 January. 
Patten R. \& Rosengard J. (1991). Progress with Profits: The Development of Rural Banking in Indonesia. San Francisco: International Center for Economic Growth and the Harvard Institute for International Development.

Republic of Indonesia (2008). Undang-Undang Republik Indonesia Nomor 20 Tahun 2008 Tentang Usaha Mikro, Kecil, Dan Menengah [Republic of Indonesia Law Number 20 Year 2008 Regarding Micro, Small, and Medium Enterprises]. Jakarta: Republic of Indonesia.

Rosengard J. (2002). Reforming the financial sectors of Thailand and Indonesia: Myth perceptions of ramakien and ramayana capitalists. Presentation at Harvard University conference on Financial Sector Reform Across Asia: Facts, Analyses, Solutions, December 10-11, Cambridge, Massachusetts.

Rosengard J., Patten R., Johnston D. \& Koesoemo W. (2007). The promise and peril of microfinance institutions in Indonesia. Bulletin of Indonesian Economic Studies, 43 (1), 87-112.

Rosengard J., Morduch J., Johnston D. et al. (2001). BRI Micro Banking Services: Development Impact and Future Growth Potential. Jakarta: PT. Bank Rakyat Indonesia and Center for Business and Government, John F. Kennedy School of Government, Harvard University.

Samboh E. (2011). RI banks lag behind ASEAN rivals. The Jakarta Post, January 24.

The Economist (2010). Indonesia banks: Profits puzzle. The Economist, October 16, 38.

Thee K. \& Negara S. (2010). Survey of recent developments. Bulletin of Indonesian Economic Studies, 46 (3), 279-308.

World Bank (2006). Revitalizing the Rural Economy: An Assessment of the Investment Climate Faced by Non-farm Enterprises at the District Level, Executive Summary and Summary of Recommendations from RICA, Vol. 1. Washington, DC: World Bank.

World Bank (2007). Revitalizing the Rural Economy: An Assessment of the Investment Climate Faced by Non-farm Enterprises at the District Level, Executive Summary and Summary of Recommendations from Main Report, Vol. 2. Washington, DC: World Bank.

World Bank (2010). Improving Access to Financial Services in Indonesia. Washington, DC: World Bank.

World Bank and International Finance Corporation (2009). Doing Business 2010: Reforming through Difficult Times. Washington, DC: World Bank, IFC, and Palgrave Macmillan. 